\title{
Higher Secondary School Students' Attitude towards Chemistry
}

\author{
Gul Nazir Khan ${ }^{1} \&$ Arshad $\mathrm{Ali}^{1}$ \\ ${ }^{1}$ Institute of Education \& Research, University of Peshawar, Peshawar, Pakistan \\ Correspondence: Gul Nazir Khan, Institute of Education \& Research, University of Peshawar, Peshawar, \\ Pakistan. E-mail: gulnazir515198@gmail.com
}

Received: November 30, 2011

Accepted: February 19, $2012 \quad$ Published: May 1, 2012

doi:10.5539/ass.v8n6p165

URL: http://dx.doi.org/10.5539/ass.v8n6p165

\begin{abstract}
The focus of this study was about higher secondary school students' attitude towards chemistry subject, chemistry teacher and teaching methodologies of chemistry teacher. Like academic achievement, attitude is considered to be an important product of higher secondary education. The population of this study was all the higher secondary schools students of Khyber Pakhtunkhwa (Pakistan), however due to time constraints and convenience the 35 second year students of government higher secondary school Jamrud Khyber agency Khyber Pakhtunkhwa were taken as convenience sample for this study. A modified questionnaire of Abulude (2009), Cheung (2009) and class room life script of Johnson and Johnson, Johnson, Johnson \& Anderson (1983), of likert scale were used as an instrument for this study. The attitude of the students was analyzed by the mean score of each statement. The study revealed that students were very much satisfied from the chemistry teacher however students have worries about the subject of chemistry and the methodology of chemistry.
\end{abstract}

Keywords: chemistry, attitude, Jamrud, Khyber Pakhtunkhwa, Pakistan

\section{Introduction}

Attitude is a hypothetical construct that indicates an individual like and dislike towards an item. It may positive, negative or neutral. Attitude is an approach, temperament, sensation, situation, etc. with regard to a person or thing: inclination or course, especially of the mind. Attitude is a way of looking at things (Muellerleile, 2005). The important outcomes of secondary school science education are attitude like academic achievement. Oskamp \& Schultz (2005) described that there are three major theoretical viewpoints about the important nature of attitudes that have been proposed by social psychologists: the tri-component point of view, the separate entities point of view, and the latent process perspective (Oskamp \& Schultz, 2005). Affect, behavior, and cognition are the three components of attitude which is a single entity the tricomponenet viewpoint holds. The thoughts and emotions one has toward an attitude object such as chemistry lessons and chemistry subject are referred to as affective point of view. The individual's explicit events and reactions to the attitude object is referred to behavior component of attitude, while the cognitive factor is the thinking or belief that someone has about the attitude object.

The three components that are affect, behavior and cognition are unique and separate entities, the second theoretical viewpoint about the nature of attitudes assumed. The term attitude reserves the effective component only. Cognition and behavior are considered as determinants instead of components of an attitude. This point of view has been described by investigators such as Thurstone (1931), Bem (1970), and Fishbein and Aizen (1975). They have described attitude as the sum of affect for or in opposition to an object.

However, some researchers (e.g., Oskamp \& Schultz, 2005; Zanna \& Rempel, 1988) distrust this simple speculative view of attitudes Fishbein and Aizen (1975) also admitted that this standpoint does not take into custody the full intricacy of the attitude impression. The third theoretical point of view views attitudes as a latent variable that can explain the connection between certain observable stimulus events and behaviors. Attitudes can be formed from cognitive, affective, and/or behavioral information about the attitude objects and expressed through cognitive, affective, and/or behavioural responses existing attitude researchers agreed (Eagly \& Chaiken, 2005; Fabrigar, MacDonald, \& Wegener, 2005; Oskamp \& Schultz, 2005). According to Oskamp and Schultz (2005), the latent process viewpoint is better than the tri-component viewpoint or the separate entities viewpoint because it is more consistent with findings of contemporary attitude research. 
In the present study, the investigators used Oskamp and Schultz's (2005) definition of attitude (i.e., an attitude is a tendency to react in a positive or negative style with respect to a given attitude object) and based on the latent process point of view students attitude towards chemistry were measured.

It is worth mentioning that the development students' positive attitude is necessary because attitude is linked with academic achievement, Cheung (2009), research have confirmed. For instance Weinburgh,s (1995) meta analysis of research have summarized that the correlation between students positive attitude towards science and academic achievement is 0.55 for girls and 0.5 for boys, representing that an attitude can account $25-30 \%$ of the variance for academic achievement. The correlation between high school students' achievement in chemistry and their attitudes toward chemistry ranged from 0.24 to 0.41 , (Salta and Tzougraki, 2004). On the basis of attitude, the prediction of behavior is possible that is another reason why it is important to develop students' positive attitude towards chemistry, (Glasman and Albarracín 2006; Kelly 1988). Similarly study conducted by Kelly (1998) concluded that the British students liking for a specific science subject were the actual predictor of their choice in school in various subjects like physics, biology and chemistry.

Every science teacher considered the development of positive attitude towards science subjects as his center responsibility (Cheung, 2009). Unluckily, what is going on in our science class rooms is not particular to the students across all ages, research has revealed, (Stark and gray 1999: Cheung 2009). According to Yara (2009), teacher, attitude and his method of teaching can greatly influenced the students' attitude. Bennett, Rollnick, Green and White (2001) also explored that the undergraduate students who had developed a lower constructive attitude towards chemistry almost always got low grade in examination.

A number of factors have been identified as related to students attitude towards chemistry, such factors include teaching methods, teacher attitude, influence of parents, gender, age, cognitive style of pupils, career interest, and social implication of chemistry and achievement, Adesogi,(2008) concluded. Olatoye (2001) found that students attitude towards chemistry have significant direct effect on students' achievement in the subject, reported by Abulude, (2009). Understanding of students' attitude is important in supporting their achievement and interest towards a particular discipline. Students attitude towards science have been extensively studied, Dhindsa \& Cheung (2003), Osborne, Simon and Collins (2003), but research was initially focused greatly on science in general (Dawson,2000) and less attention was addressed to particular discipline like biology, Physics and chemistry(Salta and Tzougraki, 2004). This can partly camouflage students attitude towards science because science is not viewed as homogenous subject, ( Spall et al , 2003). Knowing the importance of students' attitude towards chemistry, the present study addressed the following questions

\section{Research Questions}

Knowing the importance of students' attitude towards chemistry, the present study addressed the following questions:

Question: 1: What is students' attitude towards chemistry?

Question: 2: What are the students' beliefs about chemistry teacher?

Question: 3: What are the students' views about the methodology of chemistry?

\section{Methodology}

The measurement of students, attitude towards science in school is important for science educators, Osborne, Simon, \& Collins, (2003). However, how to measure them? There is much less agreement. A modified questionnaire of Abulude (2009), Cheung (2009) and class room life script of Johnson and Johnson, (1983b): Johnson, Johnson \& Anderson, (1983) were used as an instrument for this study. Permission was granted from the respective authors through emails. The questionnaire addresses three main issues students' beliefs about chemistry subject, chemistry teacher and teaching of chemistry teacher with a likert format. Students attitudinal consist of three classes: affective, cognitive, and behavioral (Oskamp and Schultz 2005). The likert scale questionnaire having 25 items were randomly distributed in the four scales. The first subscale addresses on the feelings of students towards chemistry, chemistry teacher and methodology, the second subscale focuses on liking of chemistry, the third subscale is concerned about the students' beliefs and the fourth subscale is directed towards students' behaviors. The first two scales are affective in nature, the third subscale is cognitive in nature and the fourth subscale shows students behavior tendencies. An attitude is not a behavior it an action tendency to react in specific way towards an attitude object. (Eagly and Chaiken 2005), as mentioned by Cheung (2009).

All the higher secondary schools students of Khyber Pukhtunkhwa (Pakistan) were considered as population of this study. However due to time constraints and convenience only 35 second year students of government higher secondary school Jamrud Khyber agency were taken as a convenient sampling. The attitude scale was distributed 
by the investigators personally. The attitude scale was distributed at the onset of the academic year. The attitude scale was translated into national language for students' comprehension. Each item was scored according to the formula: Strongly Agree =5, Agree =4, Undecided =3, Disagree =2, strongly disagree = 1 Best \& Kahn, (2006).

From the above score the mean of each item was calculated, Ali et al (2010), Adnan \& Ahmet (2006). From the mean of the score from each item the result are interpreted as: 1.00-2.5 = Disagree, 2.6-3.4 =Neutral, 3.5-4.5 and higher $=$ Agree .

\section{Result \& Discussion}

The data collected from the students were organized and discussed as under:

Table 1 shows that the mean of the items regarding chemistry teacher exhibited that students are very much satisfied from their teacher. Students' attitude regarding teacher accessibility, contents taught and teacher behavior were all positive.

Table 1. Students' attitude towards chemistry teacher

\begin{tabular}{|c|c|c|}
\hline Statements & $\begin{array}{l}\text { Mean } \\
\text { score }\end{array}$ & Interpretation \\
\hline 1-Your chemistry teacher is highly motivated while teaching. & 4.75 & Agree \\
\hline 2-My chemistry teacher is too lazy in looking our notes for correction. & 1.45 & Disagree \\
\hline 3-I am not very much satisfied the way chemistry teacher teach us chemistry & 1.66 & Disagree \\
\hline 4-My chemistry teacher is too harsh and incompetent & 1.12 & Disagree \\
\hline 5-My chemistry teacher do not like me as much as he likes other students & 1.45 & Disagree \\
\hline $\begin{array}{l}\text { 6-The contents taught by chemistry teacher helps me in solving chemistry } \\
\text { paper in the annual examination. }\end{array}$ & 4.4 & Agree \\
\hline $\begin{array}{l}\text { 7-You have access to your chemistry teacher when you have problems in the } \\
\text { subject of chemistry. }\end{array}$ & 3.83 & Agree \\
\hline
\end{tabular}

Table 2 represents the teaching learning process of chemistry. From the mean of the score it was clear that the students' responses about the interesting nature of the chemistry class were neutral. This neutral response might be due to one way teaching of chemistry teacher. According to Adesoji and Olatunbosun (2008), chemistry teaching is sopposed to be result oriented and students centered, and this can only be achieved when students are willing and teachers are favorably disposed, using the appropriate methods and resources in teaching the students. Usman,(2000), remarked that the brain is not the passive consumer of information and to learn with understanding, a learner must actively construct meaning of what to be learned reported by Lawrence \& Abraham(2011). There is a significant relationship between students' attitude towards chemistry and the perception of their teacher method of teaching chemistry, Angela et al (2011). When the teacher uses appropriate method of teaching the students tend to follow and grasp the knowledge, Agoha, (2005). Similarly most of the students have problems in expressing their views in front of the class.

Table 2. Students' attitude towards methodology of chemistry

\begin{tabular}{lll}
\hline Statements & $\begin{array}{l}\text { Mean } \\
\text { score }\end{array}$ & Interpretations \\
& & \\
\hline
\end{tabular}

1-You prefer private tuition in solving problems in chemistry.

2-I have a lot of questions I never get a chance to ask in the class.

3-I find it hard to speak my thoughts clearly in the chemistry class.

4-Chemistry class is not very interesting.

$\begin{array}{ll}2.4 & \text { Disagree } \\ 3.5 & \text { Agree } \\ 3.34 & \text { Neutral } \\ 2.4 & \text { Disagree }\end{array}$

Table 3 is about the subject of chemistry. The mean of the score shows that majority of the students knew and understood chemistry, although most of them considered it as an important subject needed for their course work. From the attitude scale it was also cleared that $65 \%$ of the students did not considered chemistry as their favorite subject these findings are in consistent with the findings of Abulude, (2009). 
Table 3. Students' attitude regarding chemistry subjects

\begin{tabular}{|c|c|c|}
\hline Statements & $\begin{array}{l}\text { Mean } \\
\text { score }\end{array}$ & Interpretat \\
\hline 1-Chemistry is one of the subjects you intend studying in the future. & 3.15 & Neutral \\
\hline 2-Chemistry is not needed at all in your work and course of study. & 1.8 & Disagree \\
\hline $\begin{array}{l}\text { 3-If you have an option for selecting another subject instead of chemistry, you } \\
\text { would opt for it. }\end{array}$ & 3.15 & Neutral \\
\hline 4-You believe that you know and understand chemistry. & 3.66 & Agree \\
\hline 5 -Your chemistry textbook is not found to be interesting. & 2.86 & Neutral \\
\hline 6-Only very brilliant students should study chemistry. & 2.3 & Disagree \\
\hline 7-I deserve the score I get in chemistry subject in annual examination. & 4.1 & Agree \\
\hline 8-I don't like to do chemistry experiments. & 1.83 & Disagree \\
\hline 9-I study chemistry in order to secure admission in higher classes. & 2.63 & Neutral \\
\hline 10-Chemistry is a theoretical subject and has no relation with the practical life. & 1.35 & Disagree \\
\hline 11-I doubt if I can ever pass my chemistry subject in annual examination. & 3.06 & Neutral \\
\hline 12-Personally I believe that chemistry is volatile and difficult subject. & 3.46 & Neutral \\
\hline 13-I like chemistry more than other course subjects. & 2.66 & Neutral \\
\hline 14-The concepts, theories and formulas of chemistry are too & 3.4 & Neutral \\
\hline
\end{tabular}
understand as compared to other science subjects.

These findings were also proved by the study of Jagede, (2007), who concluded that all students irrespective of their age and gender differences showed greater anxiety towards chemistry. Similarly students also disagreed to the students that chemistry is a theoretical subject and have no relation to practical life.

\section{Conclusions \& Recommendations}

The study reported that students viewed chemistry teacher as friendly, accessible, highly motivated, and competent and were satisfied from the way he taught chemistry. These findings solved the second research question about the students' views about chemistry teacher. In order to address the $3^{\text {rd }}$ question pertaining to the methodology of chemistry, students refused to prefer private tuitions for solving chemistry problems. However students have problems in expressing their views in the class. Majority of the students agreed that they understood chemistry. About the interesting nature of chemistry class students were agreed. They are satisfied from the score they got in the final term. Moreover students have mixed responses for selecting another subject instead of chemistry. Students have also a neutral response for studying chemistry in future. Students showed strong agreement about the importance of chemistry in their daily life. These were responses to the first research question regarding students' attitude towards chemistry. It is recommended on the basis of the study, that future research might be done in this regard in order to find out the root causes of the students anxiety towards chemistry.

\section{References}

Abulude, O. F. (2009). Students' attitude towards chemistry in some selected Secondary schools in Akure south local government area, Ondo state, unpublished Thesis of PGD in Education, Retrieved October 2, 2011, from http://www.scribd.com/doc/34545165/

Adesoji, F.A. (2008). Managing Students Attitude towards Science through Problem Solving Instructional Stregies. Anthropologist, 10(1), 22-24.

Adesoji. F.A., \& Olatunbosun.S. (2008). Student, Teacher and School Environmental Factors as Determinants of Achievement in Senior Secondary School Chemistry in Oyo state, Nigeria. Uluslararasi Sosyal-Ara trrmalar Dergesi. The Journal of International Social Research, 1(2).

Adnan. K., \& Ahmet. A. (2006). Affective Factors that Influence Chemistry Achievement (attitude \& self efficacy) and the Power of These Factors to predict Chemistry Achievement-1. Journal of Turkish Science Education, 3(1).

Agoha. T.C. (2005). Some correlates of students attitude towards Biology in Ikedura Government Area in Immo state. Avana Journal of science, 2(2), 1-10.

Ali. M. A.,Rauf. M., Iqbal. Z., \& Malik. M. A. (2010). Job Satisfaction of Elementary Teachers. Journal of Education and Research, 7. Institute of Education and Research University of Peshawar.

Anglena. O.D., \& Ugwuegbulan.N.C. (2011). Some Correlates of Students Attitude Towards Chemistry in Government Technical Colleges in Imo state. International Journal of Psychology and Counseling, 2(5), 90-95.

Bem, D. J. (1970). Beliefs, Attitudes, and Human affairs. Belmont, CA, Brooks/Cole. 
Bennett, J., Rollnick, M., Green, G., \& White, M. (2001). The development and use of an instrument to assess students' attitude to the study of chemistry. International Journal of Science Education, 23(8), 833-845. http://dx.doi.org/10.1080/09500690010006554

Best J .W., \& Kahn J.V. (2006). RESEARCH IN EDUCATION (9 ${ }^{\text {th }}$ ed.). Dorling Kindersley (India) Pvt. Ltd., licensees of Pearson education in South East Asia.

Cheung. D. (2009). Students' Attitudes toward Chemistry Lessons: The Interaction Effect between Grade Level and Gender. http://dx.doi.org/10.1007/s11165-007-9075-4

Cheung.D. (2009). Developing a Scale to Measure Students Attitude Towards Chemistry Lessons. International journal of science education, 31(16), 2185-2203. http://dx.doi.org/10.1080/09500690802189799

Dawson, C. (2000). Upper primary boys and girls interest in science: have they changed since 1980. International journal of science education, 22(6), 557-570. http://dx.doi.org/10.1080/095006900289660

Dhindsa, H.S., \& Cheung, G. (2003). Attitude and Achievement of Bruneian science students. International journal of science education, 25(8), 907-922. http://dx.doi.org/10.1080/09500690305025

Eagly, A. H., \& Chaiken, S. (2005). Attitude research in the 21 st century: The current state of knowledge. In D. Albarracin, B. T. Johnson, \& M. P. Zanna (Eds.), The handbook of attitudes (pp. 743-767). Mahwah, NJ: Lawrence Erlbaum Associates.

Fabrigar, L. R., MacDonald, T. K., \& Wegener, D. T. (2005). The structure of attitudes. In D. Albarracin, B. T. Johnson, \& M.P. Zanna (Eds.), The handbook of attitudes (pp. 79-124). Mahwah, NJ: Lawrence Erlbaum Associates.

Fishbein, M., \& Aizen, I. (1975). Belief, attitude, intention, and behavior: An introduction to theory and research. Reading, MA: Addison-Wesley.

Glasman, L. R., \& Albarracín, D. (2006). Forming attitudes that predict future behavior: A meta-analysis of the $\begin{array}{lllll}\text { attitude-behavior } & \text { relation. } & \text { Psychological } & \text { Bulletin, } & \text { 132(5), }\end{array}$ http://dx.doi.org/10.1037/0033-2909.132.5.778

Huskinson, T. L. H., \& Haddock, G. (2004). Individual differences in attitude structure: Variance in the chronic reliance on affective and cognitive information. Journal of Experimental Social Psychology, 40, 82-90. http://dx.doi.org/10.1016/S0022-1031(03)00060-X

Kelly, A. (1988). The customer is always right: Girls' and boys' reactions to science lessons. School Science Review, 69(249), 662-676.

Lawrence. E., \& Abraham. A. (2011). The challenge of effective teaching of chemistry: A case study. Retrieved October 21, 2011, from http://lejpt.academicdirect.org/A18/001_008.htm

Muellerleile. J. (2005). ATTITUDEVS.APTITUDE. Retrieved October 7, 2011, from http://www.4vqp.com/images/062305_Attit ude_vs_Aptitude.pdf

Osborne, J., Simon, S., \& Collins, S. (2003). Attitudes towards science: A review of the literature and its implications. International Journal of Science Education, 25(9), 1049-1079. http://dx.doi.org/10.1080/0950069032000032199

Oskamp, S., \& Schultz, P. W. (2005). Attitudes and opinions (3rd ed.). Mahwah, NJ: Lawrence Erlbaum Associates.

Salta, K., \& Tzougraki, C. (2004). Attitudes toward Chemistry among 11th grade Students in high schools in Greece. Science Education, 88(4), 535-547. http://dx.doi.org/10.1002/sce.10134

Stark .R., \& Gra. (1999). Gender preferences in learning science. International journal of science education, 21(6): 633-643.

Thurstone, L. L. (1931). The measurement of social attitudes. Journal of Abnormal and Social Psychology, 26, 249-269. http://dx.doi.org/10.1037/h0070363

Weinburgh, M. (1995). Gender differences in student attitudes toward science: A meta-analysis of the literature from 1970 to 1991. Journal of Research in Science Teaching, 32, 387-398. http://dx.doi.org/10.1002/tea.3660320407

Yara. P. Olatunde. (2009). Students attitude towards mathematics and academic achievement in some selected secondary schools in south-western Nigeria. European Journal of scientific research, 36(3), 336-341.

Zanna, M. P., \& Rempel, J. K. (1988). Attitudes: A new look at an old concept. In D. Bar-Tal \& A. W. Kruglanski (Eds.), The social psychology of knowledge (pp. 315-334). New York: Cambridge University Press. 